\title{
FAKTOR-FAKTOR YANG MEMPENGARUHI PENERAPAN AKUNTANSI AKRUAL PADA PEMERINTAH KOTA PONTIANAK
}

\begin{abstract}
This study aims to determine the extent of implementation of accrual accounting and the factors that influence the level of implementation of accrual accounting in Pontianak. This research is a survey by means of collecting data using questionnaires. The samples used were financial staff that makes the financial statements at 16 SKPD in Pontianak. The analytical tool used is multiple regression analysis. The level of implementation is measured using nine indicators adopted by the Government Accounting Standards based on Government Regulation No. 71 of 2010 consists of revenue recognition (LO), Recognition load, Valuation and Presentation of Accounts Receivable, Recognition load inventory, assessment of fixed assets, depreciation of fixed assets, recognition of liabilities, Presentation of operational reports and presentation of changes in equity. The study found that the level of implementation of accrual accounting in Pontianak at 93.09\%, and there are four factors that affect the application of accrual accounting in Pontianak is the level of education finance staff, the experience of running the cash to the accrual accounting system, leadership and educational background the size of the labor force.
\end{abstract}

Keyword : Cash Basis, Accrual Basis, Cash toward Accrual.

\section{PENDAHULUAN}

Undang Undang Nomor 17 tahun 2003 mengamanatkan instansi pemerintah baik dipusat maupun didaerah untuk menerapkan Standar Akuntansi Pemerintah berbasis akrual. Dengan adanya Undang Undang tersebut terjadi perubahan pada basis akuntansi sektor publik dari akuntansi berbasis kas menjadi akuntansi berbasis akrual.

Sebagai pedoman pelaksanaan undang-undang tersebut maka terbit Peraturan Pemerintah nomor 24 tahun 2005 tentang Standar Akuntansi Pemerintahan, yang mensyaratkan pemerintah paling lambat 5 tahun untuk menerapkan sistem akuntansi berbasis akrual, namun hingga batas waktu yang telah ditentukan, pemerintah belum berhasil menerapkan sistem akuntansi berbasis akrual tersebut, kemudian terbitlah Peraturan Pemerintah nomor 71 tahun 2010 dimana batas waktu penerapan sistem akuntansi akrual secara penuh diundur sampai dengan tahun 2014.

Dengan adanya basis akuntansi akrual diharapkan pengelolaan keuangan pemerintah baik pemerintah pusat maupun daerah lebih dapat mengungkapkan informasi-informasi yang relevan dalam upaya pengambilan keputusan karena sistem akuntansi akrual ini memberikan pengukuran yang lebih baik serta pengakuan yang tepat waktu. Akuntansi akrual ini diyakini akan mewujudkan transparansi dan akuntabelnya pengelolaan keuangan di sektor publik. Van Der Hoek dalam Irvan (2012) mengemukakan manfaat sistem akuntansi berbasis akrual diantaranya, mendukung manajemen kinerja, memfasilitasi manajemen keuangan yang lebih baik, memperbaiki pengertian akan biaya program, memperluas dan meningkatkan informasi alokasi sumber daya, meningkatkan kualitas pelaporan keuangan serta meningkatkan manajemen asset.

Korespondensi dengan penulis: 
Namun sampai saat ini, penerapan basis akuntansi akrual belum terealisasi secara baik, Menurut Simanjuntak (2010), beberapa tantangan penerapan akuntansi berbasis akrual di pemerintahan Indonesia adalah sebagai berikut: Sistem akuntansi dan Information Technology (IT) Based System, Komitmen dari Pimpinan, Tersedianya Sumber Daya Manusia (SDM) yang Kompeten, Resistensi Terhadap Perubahan, Lingkungan/Masyarakat.

Belum terealisasinya penerapan sistem akuntansi akrual di Indonesia secara baik menurut Solikhin (2007) disebabkan kesiapan pemerintah Indonesia yang masih kurang atas penerapan Standar Akuntansi Pemerintah. Pada beberapa negara yang menerapkan akuntansi berbasis akrual, yang menjadi faktor penghambat penerapan basis akrual ini adalah permasalahan akuntansi, sumber daya manusia, organisasi dan keuangan sehingga transisi sistem akuntansi dari basis kas menjadi akrual tidak dapat terjadi secara cepat.

Lebih lanjut Muhammad (2013) mengemukakan bahawa keberhasilan atau kegagalan penerapan akuntansi berbasis akrual pada pemerintah tidak lepas dari peran satuan kerja dan pengaruh dari faktorfaktor yang ada pada satuan kerja tersebut mulai dari faktor sumber daya manusia seperti tingkat pendidikan staf, pelatihan yang diberikan, latar belakang pendidikan pimpinan, faktor organisasional seperti kualitas teknologi informasi dan dukungan konsultan maupun faktor situsional seperti pengalaman satuan kerja dalam menjalankan basis kas menuju akrual serta ukuran dari satuan kerja tersebut.

Kota Pontianak merupakan salah satu pemerintah daerah di Indonesia yang juga harus menerapkan sistem akuntansi berbasis akrual seperti yang diamanatkan oleh Undang-Undang, pada penelitian ini, peneliti ingin mengetahui bagaimana penerapan akuntansi berbasis akrual di kota Pontianak dan faktor-faktor apa saja yang mempengaruhi penerapan sistem akuntansi akrual tersebut.

Penelitian ini mereplikasi penelitian Muhammad (2013) yang meneliti tentang faktor-faktor yang mempengaruhi tingkat penerapan akuntansi akrual pada pemerintah dengan objek satuan kerja dalam wilayah kerja Kantor Pelayanan Perbendaharaan Negara (KPPN) Semarang I, hasil penelitiannya menemukan bahwa tingkat penerapan akuntansi akrual pada KPPN Semarang I masih rendah, tingkat penerapan akuntansi akrual dipengaruhi secara signifikan hanya oleh faktor pelatihan staf keuangan, namun faktor tingkat pendidikan staf, kualitas teknologi informasi, dukungan konsultan, pengalaman, latar belakang pendidikan pimpinan dan ukuran satuan kerja tidak mempengaruhi tingkat penerapan akuntansi akrual.

Sesuai dengan latar belakang diatas, maka yang menjadi permasalahan dalam penelitian ini adalah bagaimana penerapan sistem akuntansi berbasis akrual serta faktor-faktor apa saja yang mempengaruhi tingkat penerapan sistem akuntansi berbasis akrual di kota Pontianak?

\section{KERANGKA TEORITIS DAN PENGEMBANGAN HIPOTESIS}

Basis akuntansi adalah metode pencatatan akuntansi kapan dan bagaimana suatu transaksi diakui atau dicatat. Secara teori ada dua basis akuntansi yang dapat digunakan dalam pencatatan bukti transaksi yaitu basis kas dan basis akrual. Basis kas adalah basis yang mengakui transaksi pada saat kas atau setara kas diterima atau dibayar sedangkan basis akrual mengakui transaksi tanpa memperhatikan apakah kas atau setara kas diterima atau dibayarkan.

Jurnal Akuntansi Indonesia 
Baik basis kas maupun basis akrual masing-masing memiliki kelemahan maupun keunggulan. Menurut Ritonga, basis kas memiliki keunggulan dalam memperlihatkan sumber dana, alokasi dan penggunaan sumber-sumber kas, mudah untuk dimengerti dan dijelaskan, pembuat laporan keuangan tidak membutuhkan pengetahuan yang mendetail tentang akuntansi, dan tidak memerlukan pertimbangan ketika menentukan jumlah arus kas dalam suatu periode. Sedangkan kelemahannya menurut Hoesada (2010) adalah tidak mampu menyajikan jumlah sumberdaya yang digunakan serta tidak mampu memperhitungkan atau mempertimbangkan kewajiban keuangan, hutang, komitmen masa depan, penjaminan oleh pemerintah, atau kewajiban kontinjen, terfokus secara sempit pada pembayaran kas, tidak peduli akan kondisi dan daya layan aset tetap, terfokus pada pengendalian input, pembelian, perolehan, dan mengabaikan produksi sendiri.

Kelemahan basis kas tersebutlah yang melatarbelakangi terjadinya perubahan di sektor publik dengan merubah basis akuntansi kas menjadi basis akuntansi akrual, International Public Sector Accounting Standards Board (2011) dalam Muhamad (2013), mengatakan bahwa informasi yang disajikan pada basis akrual memungkinkan untuk: menunjukkan bagaimana pemerintah membiayai aktivitas-aktivitasnya dan memenuhi kebutuhan dananya, memungkinkan pengguna laporan untuk mengevaluasi kemampuan pemerintah saat ini untuk membiayai aktivitas-aktivitasnya dan untuk memenuhi kewajiban-kewajian dan komitmenkomitmennya, menunjukkan posisi keuangan pemerintah dan perubahan posisi keuangannya, memberikan kesempatan pada pemerintah untuk menunjukkan keberhasilan pengelolaan sumber daya yang dikelolany serta bermanfaat untuk mengevaluasi kinerja pemerintah dalam hal efisiensi dan efektifivitas penggunaan sumber daya.

Adanya Undang-Undang nomor 17 tahun 2003 tentang keuangan Negara yang mengharuskan adanya suatu standar akuntansi pemerintahan dalam membuat laporan keuangan baik pemerintah pusat maupun daerah. Didalam undang-undang tersebut juga terdapat jangka waktu paling lama 5 tahun terhitung semenjak terbit yang mewajibkan pengakuan dan pengukuran pendapatan dan belanja berbasis akrual.

Karena dalam praktiknya belum siapnya pemerintah baik pusat maupun daerah dalam melaksanakan pelaporan keuangan yang berbasis akrual, maka sebagai amanat dari undang-undang nomor 17 tahun 2003 tersebut maka terbitlah Peraturan Pemerintah nomor 71 tahun 2010 yang meliputi Standar Akuntansi Pemerintah berbasis akrual yang berlaku sejak tanggal ditetapkannya dan dapat segera diterapkan oleh setiap entitas dan Standar Akuntansi Pemerintah berbasis kas menuju akrual berlaku selama masa transisi bagi entitas yang belum siap untuk menerapkan standar akuntansi berbasis akrual dengan batas akhir pelaksanaan yaitu sampai dengan akhir tahun 2014.

\section{METODE PENELITIAN}

Bentuk penelitian ini adalah survey. Penelitian survey merupakan suatu penelitian yang dilakukan dengan mengambil sampel dari populasi dengan menggunakan kuesioner sebagai alat pengumpulan data pokok (Singarimbun dan Effendy, 1995:3).

Variabel independent dalam penelitian ini menggunakan 7 indikator terdiri dari tingkat pendidikan staf keuangan, pelatihan staf keuangan, kualitas teknologi informasi, dukungan konsultan, pengalaman 
menjalankan sistem akuntansi kas menuju akrual, latar belakang pendidikan pimpinan, dan ukuran satuan kerja. Sedangkan variabel dependent dalam penelitian ini adalah indeks tingkat penerapan akuntansi berbasis akrual sesuai dengan Standar Akuntansi Pemerintahan yang didasarkan pada PP nomor 71 tahun 2010 yang terdiri dari 9 indikator yang diukur secara dikotomis. Adapun ke-9 indikator tersebut adalah pengakuan pendapatan (LO), pengakuan beban, penilaian dan penyajian piutang, pengakuan beban persediaan, penilaian aset tetap, depresiasi aset tetap, pengakuan kewajiban, penyajian laporan operasional, serta penyajian laporan perubahan ekuitas.

Yang menjadi sampel dalam penelitian ini adalah SKPD yang terdiri dari Dinas dan Kecamatan yang berjumlah 16 SKPD. Alat analisis yang digunakan adalah analisis regresi berganda, sesuai dengan persyaratan regresi maka dilakukan uji asumsi klasik terhadap model.

\section{HASIL DAN PEMBAHASAN}

Penelitian ini menggunakan kuesioner sebagai alat pengumpul data. Untuk mengetahui tingkat penerapan akuntansi berbasis akrual sesuai dengan Standar Akuntansi Pemerintahan yang didasarkan pada PP nomor 71 tahun 2010 menggunakan 9 indikator yang diukur secara dikotomis. Hasil uji reliabilitas terhadap 9 indikator ini ada dalam tabel 1.

Dari hasil uji reliabilitas diatas, didapat nilai alpha cronbachnya sebesar 0.694, jadi karena nilai ini lebih besar dari 0,6 maka dapat dikatakan bahwa item pertanyaan relibel. Kemudian dari hasil kuesioner didapat tingkat penerapan akuntansi berbasis akrual pada 16 SKPD yang ada di kota Pontianak dengan menggunakan 9 indikator. Berdasarkan tabel 2, berdasarkan 9 indikator yang diteliti, maka tingkat penerapan akuntansi berbasis akrual pada kota Pontianak sebesar 93,09\%. Kemudian untuk mengetahui faktor-faktor yang mempengaruhi tingkat penerapan sistem akuntansi berbasis akrual di kota Pontianak, karena menggunakan analisis regresi linier berganda maka dilakukan uji asumsi terhadap model regresi. Uji asumsi yang digunakan ada 4 yaitu uji multikolinearitas, uji heteroskedastisitas, uji autokorelasi dan ujinormalitas.

Untuk mendeteksi adanya multikolinearitas dilihat dari Variance Inflation Factor (VIF). Apabila nilai VIF > 10 maka terjadi multikolinearritas dan sebaliknya apabila VIF $<10$ maka tidak terjadi multikolinearitas (Aliman, 2001:27). Dalam penelitian ini diperoleh VIF seperti pada tabel 4.3 sebagai berikut :

Dari tabel 3 dapat disimpulkan bahwa untuk semua variabel tidak terjadi multikolinearitas dengan ditunjukkan nilai VIF lebih kecil dari 10. Kemudian dilakukan uji asumsi yang kedua yaitu uji heteroskedastisitas, heteroskedastisitas akan mengakibatkan penaksiran koefisien-koefisien regresi menjadi tidak efisien, hasil penaksiran akan menjadi kurang dari semestinya. Untuk menguji tidak terjadinya heteroskedastisitas dilakukan dengan melakukan uji glejser. Rule of thumb yang digunakan adalah bila hasil signifikansi lebih besar dari 5\% maka dalam model todak terjadi heteroskedastisitas. Hasil uji heteroskedastisitas. Dari tabel 4, dapat disimpulkan bahwa tidak terjadi heteroskedastisitas pada semua variabel yang diuji. Kemudian dilakukan uji asumsi yang ketiga yaitu uji autokorelasi, Adanya suatu autokorelasi bertentangan dengan salah satu asumsi dasar dari regresi berganda yaitu tidak adanya korelasi diantara galat acaknya. Artinya jika ada autokorelasi maka dapat dikatakan bahwa koefisien korelasi yang diperoleh kurang akurat.

Jurnal Akuntansi Indonesia

160

Vol. 6 No. 2 Juli 2017 
Untuk mengetahui adanya autokorelasi digunakan uji Durbin-Watson yang bisa dilihat dari hasil uji regresi berganda. Hasil uji Durbin-Watson. Dari tabel 5 tampak bahwa nilai DW sebesar 1,087. Selanjutnya untuk mengetahui apakah terjadi autokorelasi atau tidak pada model dilakukan dengan cara membandingkan nilai DW dengan tabel DW, hasilnya dapat dilihat pada tabel 6

Jadi uji Durbin-Watson tidak dapat mendeteksi ada / tidaknya autokorelasi pada model. Jadi dilakukan pengujian lebih lanjut dengan menggunakan uji BG (Breusch - Godfrey). Hasil uji BG dapat dilihat pada tabel 7 .Dari tabel tersebut, tampak variabel residual (res 2) memberikan probabilitas signifikansi sebesar 1,104, nilai ini lebih besar dari 5\%, jadi dapat disimpulkan bahwa pada model tidak terjadi autokorelasi.

Kemudian dilakukan uji asumsi yang terakhir yaitu uji asumsi normalitas dengan menggunakan normal probability plot, hasil uji normalitas dapat dilihat pada gambar 1. tampak bahwa data terdistribusi secara normal.

Setelah dilakukan uji asumsi klasik, maka dilakukan analisis regresi dalam rangka mengetahui faktorfaktor apa saja yang mempengaruhi tingkat penerapan sistem akuntansi berbasis akrual di kota Pontianak. Hasil regresi dapat dilihat pada tabel 8.

Variabel dependen pada regresi ini adalah Penerapan Akuntansi Berbasis Akrual (Y) sedangkan variabel independennya adalah Tingkat pendidikan staf keuangan (X1), Pelatihan Staf Keuangan (X2), Kualitas Teknologi Informasi (X3), Dukungan Konsultan (X4), Pengalaman menjalankan sistem akuntansi kas menuju akrual (X5), Latar belakang pendidikan pemimpin (X6), dan Ukuran satuan kerja (X7). Model regresi berdasarkan hasil analisis di atas adalah :

$$
Y=-14,902-0,257 X 1-0,066 X 2+0,017 X 3+0,121 X 4+2,671 X 5+0,291 X 6-0,351 X 7+e
$$

Tampak pada persamaan tersebut menunjukkan angka yang signifikan pada Tingkat pendidikan staf keuangan (X1), Pengalaman Menjalankan Sistem Akuntansi Kas Menuju Akrual (X5), Latar Belakang Pendidikan Pemimpin (X6) dan Ukuran Satuan Kerja (X7). Jadi dapat disimpulkan bahwa faktor-faktor yang mempengaruhi penerapan akuntansi berbasis akrual pada kota Pontianak ada 4 faktor yaitu :Tingkat pendidikan staf keuangan, Pengalaman Menjalankan Sistem Akuntansi Kas Menuju Akrual, Latar Belakang Pendidikan Pemimpin, Ukuran satuan kerja

\section{Daftar Pustaka}


Abdul Hafiz Tanjung. 2013. Akuntansi Pemerintah Daerah Berbasis Akrual : Pendekatan Teknis Sesuai PP No. 71/2010. Penerbit Alfabeta. Bandung.

Ghozali, Iman. 2013. Apilkasi Analisis Multivariate Dengan Program IBM SPSS 21. Badan Penerbit Universitas Diponegoro. Semarang.

Gujarati, Damodar. 1997. Basic Econometrics. McGraw-Hill, Inc. Sumarno Zain (penterjemah). Ekonometrika Dasar, Penerbit Erlangga. Jakarta.

Hoesada, Jan. 2010. Accrual Budgeting and Accrual Accounting pada Pemerintahan NKRI. Jurnal Akuntansi/Tahun XIV, No. 01.

Koncoro, M. 2003. Metode Riset untuk Bisnis dan Ekonomi : Bagaimana Meneliti dan Menulis Tesis. Erlangga. Jakarta.

Irvan. 2012. Akuntansi Berbasis Akrual. http://irvandesmalcpa.wordpress.com/tag

Muhammad Ahyaruddin. 2013. Tantangan Penerapan Akuntansi Berbasis Akrual di Pemerintahan Indonesia. Internet.

Muhammad Indra Yudha Kusuma. 2013. Analisis Faktor-Faktor yang Mempengaruhi Tingkat Penerapan Akuntansi Akrual Pada Pemerintahan, Skripsi.

Ritonga. Rahmansyah. Kas Basis Vs Akrual Basis. Widyaiswara BDK. Medan.

Simanjuntak, Binsar. 2010. Penerapan Akuntansi Akrual di sektor Pemerintahan di Indonesia. Disampaikan pada Kongres XI Ikatan Akuntan Indonesia. Jakarta.

Singaribun, Masri dan Effendi, Sofian. 1995. Metode Penelitian Survey. LP3ES. Jakarta

Peraturan Pemerintah Nomor 71 Tahun 2010 tentang Standar Akuntansi Pemerintahan 


\section{Lampiran:}

Tabel 1

Hasil Uji reliabilitas

Reliability Statistics

\begin{tabular}{|r|r|}
\hline $\begin{array}{c}\text { Cronbach's } \\
\text { Alpha }\end{array}$ & N of Items \\
\hline .694 & 10 \\
\hline
\end{tabular}

Tabel 2

Tingkat Penerapan Akuntansi Berbasis Akrual

\begin{tabular}{|c|c|c|}
\hline Indikator & Tingkat Penerapan & $\%$ \\
\hline \multirow{3}{*}{ Pengakuan pendapatan (LO) } & $\begin{array}{l}\text { Dalam membuat Laporan Operasional (LO), pendapatan } \\
\text { diakui pada saat timbulnya hak atas pendapatan tersebut. }\end{array}$ & $100 \%$ \\
\hline & & \\
\hline & $\begin{array}{l}\text { Pendapatan Asli Daerah dan Pendapatan Daerah lainnya } \\
\text { diakui/dicatat ketika timbulnya hak atas pendapatan yang } \\
\text { dapat disertai atau tidak disertai dengan penerimaan kas }\end{array}$ & $100 \%$ \\
\hline Pengakuan beban & $\begin{array}{l}\text { Beban diakui pada saat timbulnya kewajiban/terjadinya } \\
\text { konsumsi asset/terjadinya penurunan manfaat ekonomi } \\
\text { atau potensi jasa yang tidak disertai atau dapat disertai } \\
\text { dengan pengeluaran kas }\end{array}$ & $100 \%$ \\
\hline \multirow[t]{2}{*}{$\begin{array}{l}\text { Penilaian dan penyajian } \\
\text { piutang }\end{array}$} & $\begin{array}{l}\text { Jika memiliki piutang, SKPD akan mengakui beban } \\
\text { penyisihan piutang dan menyajikannya di Laporan } \\
\text { Operasional }\end{array}$ & $81 \%$ \\
\hline & SKPD telah menyajikan penyisihan piutang di Neraca & $81 \%$ \\
\hline Pengakuan beban persediaan & $\begin{array}{l}\text { SKPD telah mengakui/mencatat dan menyajikan jumlah } \\
\text { pemakaian persediaan sebagai beban persediaan di } \\
\text { Laporan Operasional }\end{array}$ & $100 \%$ \\
\hline Penilaian asset tetap & $\begin{array}{l}\text { SKPD telah menyajikan asset tetap di Neraca sebesar nilai } \\
\text { tercatat bruto beserta akumulasi penyusutannya }\end{array}$ & $100 \%$ \\
\hline Depresiasi asset tetap & $\begin{array}{l}\text { SKPD telah mencatat dan menyajikan penyusutan asset } \\
\text { tetap/asset tidak berwujud sebagai beban penyusutan/ } \\
\text { amortisasi dalam Laporan Operasional }\end{array}$ & $81 \%$ \\
\hline Pengakuan kewajiban & $\begin{array}{l}\text { SKPD mengakui kewajiban pada saat melakukan } \\
\text { pembelian barang dan jasa yang telah dilaksanakan } \\
\text { walaupun pelunasan belum dilakukan }\end{array}$ & $81 \%$ \\
\hline Penyajian laporan operasional & SKPD telah menyusun Laporan Operasional & $100 \%$ \\
\hline \multirow[t]{2}{*}{$\begin{array}{l}\text { Penyajian laporan perubahan } \\
\text { ekuitas }\end{array}$} & SKPD telah menyusun Laporan Perubahan Ekuitas & $100 \%$ \\
\hline & & $93,09 \%$ \\
\hline
\end{tabular}


Tabel 3

Hasil Uji Multikolinearitas

\begin{tabular}{|c|c|c|}
\hline Variabel Independen & NILAI VIF & KETERANGAN \\
\hline $\begin{array}{l}\text { Tingkat pendidikan staf keuangan } \\
\text { (X1) }\end{array}$ & 4,183 & Tidak ada indikasi kolinearitas antar variabel \\
\hline Pelatihan staf keuangan (X2) & 1,695 & Tidak ada indikasi kolinearitas antar variabel \\
\hline Kualitas teknologi informasi (X3) & 1,610 & Tidak ada indikasi kolinearitas antar variabel \\
\hline Dukungan konsultan (X4) & 2,604 & Tidak ada indikasi kolinearitas antar variabel \\
\hline $\begin{array}{l}\text { Pengalaman menjalankan sistem } \\
\text { akuntansi kas menuju akrual (X5) }\end{array}$ & 3,709 & Tidak ada indikasi kolinearitas antar variabel \\
\hline $\begin{array}{l}\text { Latar belakang pendidikan } \\
\text { pemimpin }(X 6)\end{array}$ & 4,002 & Tidak ada indikasi kolinearitas antar variabel \\
\hline Ukuran Satuan Kerja (X7) & 2,492 & Tidak ada indikasi kolinearitas antar variabel \\
\hline
\end{tabular}

Tabel 4

Hasil Uji Heteroskedastisitas

\begin{tabular}{lll}
\hline \multicolumn{1}{c}{ Variabel Independen } & Sig & Keterangan \\
\hline Tingkat pendidikan staf keuangan (X1) & 0,686 & Homoskedastisitas \\
Pelatihan staf keuangan (X2) & 0,080 & Homoskedastisitas \\
$\begin{array}{l}\text { Kualitas teknologi informasi (X3) } \\
\text { Dukungan konsultan (X4) }\end{array}$ & 0,934 & Homoskedastisitas \\
$\begin{array}{l}\text { Pengalaman menjalankan sistem akuntansi kas menuju } \\
\text { akrual (X5) }\end{array}$ & 0,973 & Homoskedastisitas \\
Latar belakang pendidikan pemimpin (X6) & 0,634 & Homoskedastisitas \\
Ukuran Satuan Kerja (X7) & 0,120 & Homoskedastisitas \\
\hline
\end{tabular}


Tabel 5

Hasil Uji Autokorelasi

Model Summaryb

\begin{tabular}{|c|c|}
\hline Model & $\begin{array}{l}\text { Durbin- } \\
\text { Watson }\end{array}$ \\
\hline 1 & $1.087^{a}$ \\
\hline
\end{tabular}

a. Predictors:

(Constant), X7, X6

b. Dependent

Variable: $Y$

Tabel 6

Hasil Uji Durbin Watson

\begin{tabular}{cccccl}
\hline$d l$ & $d u$ & $4-d u$ & $4-d l$ & $d w$ & Interprestasi \\
\hline 0,3981 & 2,6241 & 1,3759 & 3,6019 & 1,087 & $\begin{array}{l}\text { Hasilnya tidak dapat disimpulkan } \\
\text { karena nilai DW terletak diantara dl } \\
\text { (batas bawah) dan du (batas atas) }\end{array}$ \\
\hline
\end{tabular}

Tabel 7

Hasil Uji BG

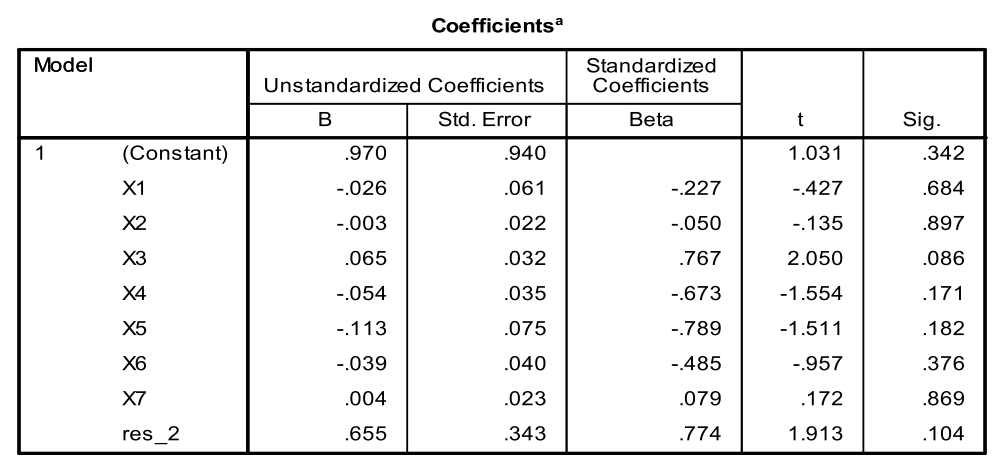

a. Dependent Variable: Unstandardized Residual 
Tabel 8

Hasil Analisis Regresi

\begin{tabular}{|c|c|c|c|c|}
\hline Variabel & $\begin{array}{l}\text { Unstandardized } \\
\text { Coefficients (B) }\end{array}$ & Thit. & Sig. & Keterangan \\
\hline (Constant) & $-14,902$ & & & \\
\hline Tingkat pendidikan staf keuangan (X1) & $-0,257$ & $-2,564$ & 0,033 & Signifikan \\
\hline Pelatihan staf keuangan (X2) & $-0,066$ & $-2,001$ & 0,080 & Tidak Signifikan \\
\hline Kualitas teknologi informasi (X3) & 0,017 & 0,389 & 0,708 & Tidak Signifikan \\
\hline Dukungan konsultan (X4) & 0,121 & 2,226 & 0,057 & Tidak Signifikan \\
\hline $\begin{array}{l}\text { Pengalaman menjalankan sistem akuntansi kas } \\
\text { menuju akrual (X5) }\end{array}$ & 2,671 & 22,781 & 0,000 & Signifikan \\
\hline Latar belakang pendidikan pemimpin (X6) & 0,291 & 4,439 & 0,002 & Signifikan \\
\hline Ukuran Satuan Kerja (X7) & $-0,351$ & $-10,963$ & 0,000 & Signifikan \\
\hline $\begin{array}{l}\text { R } \\
\text { R Square } \\
\text { Sign. F } \\
\text { a }\end{array}$ & & $\begin{array}{l}=0,996 \\
=0,993 \\
=0.000 \\
=0.05\end{array}$ & & \\
\hline
\end{tabular}

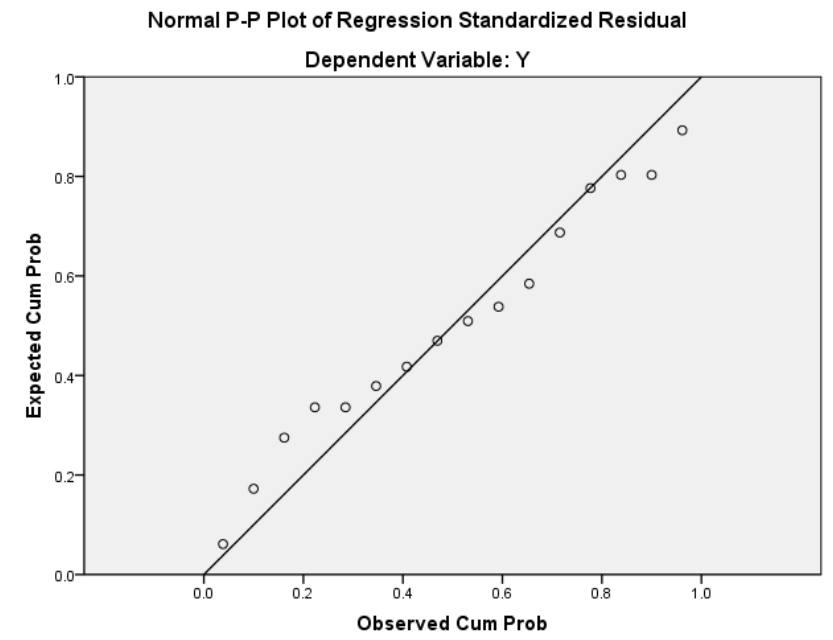

\section{Gambar 1}

Hasil uji Normalitas 